\title{
EFEKTIVITAS DAN POTENSI RISIKO PHYSICAL DISTANCING PADA MASA PANDEMI
}

\section{Effectiveness and Potential Risks of Physical Distancing during the Pandemic}

Joko Tri Atmojo ${ }^{1}$, Ahmad Rois Syujak ${ }^{1}$,Daryanto ${ }^{1}$, Sita Wahyu Dwi Jayanti ${ }^{1}$,Suciyati ${ }^{1}$,Heni Ernawati ${ }^{1}$, Sri Iswahyuni ${ }^{1}$, Rejo ${ }^{1}$, Catur Setyorini ${ }^{1}$,

Kiki Puspitasary ${ }^{1}$, Lilik Hanifah ${ }^{1}$,Sri Sayekti Heni Sunaryanti ${ }^{1}$, Tri Yuniarti ${ }^{1}$, Isnani Nurhayati ${ }^{1}$, Sri Widayati ${ }^{1}$, Widodo $^{1}$, Paidi ${ }^{1}$, Ndaru Syukma Putra ${ }^{1}$, Mega Puspita Sari ${ }^{1}$, Anggie Pradana Putri ${ }^{2}$, Saras Kuntari $^{3}$, RinaTri Handayani ${ }^{4}$, Aquartuti Tri Darmayanti ${ }^{5}$, Aris Widiyanto ${ }^{5}$, Ahmad Syauqi Mubarok ${ }^{5}$

\author{
${ }^{1}$ Satgas COVID-19 STIKES Mamba ul Ulum Surakarta \\ ${ }^{2}$ National Taipei University of Nursing and Health SciencesTaiwan \\ ${ }^{3}$ Pencegahan dan Pengendalian Penyakit, Dinas Kesehatan Kabupaten Klaten \\ ${ }^{4}$ Himpunan Alumni Magister Psikologi, Universitas Muhammadiyah Surakarta \\ ${ }^{5}$ Ikatan Alumni Magister Ilmu Kesehatan Masyarakat, Universitas Sebelas Maret \\ (jokotriatmojo1@gmail.com)
}

\begin{abstract}
ABSTRAK
Latar Belakang: COVID-19 memiliki manifestasi hingga sindrom gangguan pernapasan akut, syok septik, kegagalan nafas, bahkan kematian.Tindakan pencegahan untuk mengurangi penyebaran infeksi termasuk physical distancing telah diterapkan hampir diseluruh dunia, namun efektifitas dan potensi risiko masih belum diketahui secara mendalam.

Tujuan: Tinjauan sistematis ini akan membahas mengenai efektifitas dan potensi risiko dari physical distancingberdasarkan laporan dari kasus pandemic MERS dan COVID-19.

Metode: Proses pencarian artikel melalui basis data sejak Januari-Maret 2021 melalui berbagai basis data: PUBMED, MEDLINE, CINAHL, dan Google Scholar dengan rentang publikasi artikel antara tahun 2010-2020. Kata kunci yang digunakan adalah "Physical distancing and COVID-19" ATAU "social distancing and COVID-19", ATAU "physical distancing and MERS and COVID-19" ATAU "physical distancing and infectious disease" ATAU "efektifitas penjarakan sosial dan COVID-19".

Hasil:Physical distancing dapat mengurangi risiko kejadian MERS sebanyak 0.23 kali $\mathrm{RR}=0.23(95 \% \mathrm{CI}=0.04-1.20)$ dan SARS-CoV2 atau COVID-19 sebesar 0.20 kali $\mathrm{RR}=0.20(95 \% \mathrm{CI}=0.10-0.41)$. Efek jangka panjang physical distancing adalah meningkatkan kemungkinan kecemasan, depresi, psikosis dan gangguan neuropsikiatriyang sama seperti pandemi flu pada awal abad ke-20.
\end{abstract}


Simpulan: Menjaga jarak fisik dan interaksi sosial merupakan salah satu upaya pengendalian infeksi dengan tujuan melemahkan dan melandaikan kurva pandemi. Upaya lain yang harus dilakukan bersamaan dengan physical distancing antara lain: memakai masker, sering mencuci tangan di air mengalir menggunakan sabun, menjauhi kerumunan, dan selalu menerapkan kebersihan diri.

Kata kunci:Efektivitas, Jaga Jarak, Potensi Risiko

\section{ABSTRACT}

Background: COVID-19 has manifestations up to acute respiratory distress syndrome (ARDS), septic shock, respiratory failure, and even death. Preventive measures to reduce the spread of infection, including physical distancing, have been implemented almost all over the world. However, its effectiveness and potential risks are still not known in depth.

The Purpose: This systematic review will discuss the effectiveness and potential risks of physical distancing based on reports from the MERS and COVID-19 pandemic cases.

Method: The process of searching for articles through databases from January to March 2021 through various databases such as: PUBMED, MEDLINE, CINAHL, and Google Scholar with a range of publication of articles between 2010-2020. The keywords used are "Physical distancing and COVID-19" OR "social distancing and COVID-19", OR "physical distancing and MERS and COVID-19" $O R$ "physical distancing and infectious disease" OR "social distancing and COVID-19 effectiveness. 19 ".

Results: physical distancing can reduce the risk of MERS incidence by 0.23 times $R R=0.23(95 \% C I=0.04-1.20)$ and SARS-CoV2 or COVID-19 by 0.20 times $R R=0.20(95 \% C I=0.10-0.41)$. The long-term effect of physical distancing is to increase the likelihood of anxiety, depression, psychosis and the same neuropsychiatric disorders as the flu pandemic in the early 20th century.

Conclusion: Physical confinement and social interaction is one of the efforts to control infection with the aim of weakening and smoothing the pandemic curve. However, other efforts that must be done simultaneously with physical distancing include: wearing masks, washing hands frequently in running water using soap, staying away from crowds, and always applying personal hygiene.

Keyword:Effectiveness, Physical Distancing, Potential Risk

\section{PENDAHULUAN}

Virus influenza merupakan penyebab penyakit pernafasan ringan, namundapat menyebabkan epidemi bahkan pandemi global. Kira-kira 10\% sampai $15 \%$ orang di seluruh duniatertular berbagai virus influenza setiap tahun, dengan tingkat serangan setinggi 50\% selama epidemi besar. Infeksi beberapa jenis virus influenza telah menyebabkan pandemi global. Pada tahun 2003 epidemi sindrom pernafasan akut yang parah / Severe Acute Respiratory 
Syndrome (SARS) menyerang sekitar 8.000 orang, menewaskan 780 orang dan menyebabkankrisis sosial dan ekonomi yang sangat besar. Pada tahun 2006 unggas baru H5N1, dan pada tahun 2009 ancaman pandemi flu babi H1N1 baru, menyebabkan global(Jefferson et al., 2020).

Pada Maret 2020 seluruh dunia dikejutkan oleh penetapan status pandemi global oleh Organisasi Kesehatan Dunia (WHO) karena jenis baru virus influenza yakni Severe Acute Respiratory Syndrome- Coronavirus Type 2 (SARS-CoV2) atau Coronavirus Disease 2019 (COVID-19) (World Health Organization, 2020).

COVID-19 memiliki manifestasi penyakit mulai dari flu biasa hingga gangguan pernapasan yang parah telah terbukti berkembang menjadi sindrom gangguan pernapasan akut (ARDS) dan syokseptikbahkan kegagalan nafas yang berakibat fatal(Andersen et al., 2020).Secara global hingga 3 Maret 2021 tercatat ada 115.191.150 kasus, bahkan di Indonesia jumlah kasus infeksi telah mencapai 1,3 juta kasus.

Tindakan pencegahan untuk mengurangi penyebaran infeksi termasuk menjaga kebersihan diri, mengutamakan cuci tangan, membersihkan ponsel dan barang pribadi lainnya, menerapkan etika batuk, memakai masker dan menjaga jarak sosial setidaknya 6 kaki dari orang lain, menghindari keramaian, meminimalkan penggunaan transportasi umum, dan mengikuti protokol di ruang kerjadan karantina menjadi sangat penting dilakukan. Penggunaan maskerpunharus memperhatikan manfaat, masker kain 3 lapis untuk masyarakat umum guna mendapatkan perlindungan maksimal selama pandemi harus diikuti protokol kesehatan lainnya (Atmojo et al., 2020).Pandemi masa lalu, tindakan menjaga jarak sosial yang ekstrim seperti isolasi dan karantinaterbukti memicu depresi dan kecemasan(Park, Kim and Lee, 2020). Selama pandemi Covid-19 tenaga kesehatan mengalami tekanan psikologis, diantaranya adanya gangguan kecemasan dan depresi yang disebabkan oleh faktor internal, eksternal dan lingkungan kerja (Handayani et al., 2020; Rejo et al., 2020).

Dampak dari sosial dan physical distancing pada penularan infeksi dan efektifitasnya dan potensi risiko masih belum diketahui secara mendalam. Penelitian ini akan memberikan tinjauan sistematis mengenai efektifitas dan potensi risiko dari physical distancing pada penularan infeksi virus influenza berdasarkan laporan dari kasus pandemic MERS dan COVID-19.

\section{METODE PENELITIAN}

\section{Strategi Pencarian}

Artikel dicari melalui basis data sejak Januari - November 2020. Pencarian diperoleh dari berbagai database seperti: PUBMED dan Google Scholar. Tidak ada upaya dari penulis untuk mencari secara spesifik artikel-artikel yang tidak terpublikasi. Kata kunci yang digunakan adalah "physical distancing and COVID-19"ATAU "social distancing and COVID-19", ATAU "physical distancing and MERS and COVID-19"ATAU"physical distancing and infectious disease" ATAU "efektifitas penjarakan sosial dan COVID-19". 


\section{Kriteria Inklusi}

Artikel yang terpublikasi menggunakan bahasa Inggris atau Indonesia.Free full text atau artikel yang dapat diunduh secara gratis (open access). Desain studi yang digunakan adalah observasional berupa COHORT Retrospektif yang terpublikasi antara tahun 2010-2021.

\section{Kriteria Eksklusi}

Artikel yang terpublikasi menggunakan bahasa Cina, Jepang, Spanyol, dan Arab.Subyek berusia kurang dari19 tahun. Artikel dengan desain studi kasus, quasi eksperimental, RCT, Cross-sectional, case report, dan kasus kontrol.

\section{Strategi Penilaian Kualitas dan Sintesis Data}

Semua studi yang teridentifikasi dinilai secara independen oleh seluruh penulis untuk relevansi berdasarkan judul dan abstrak, kemudian versi teks lengkap dari semua kemungkinan relevan, ketidaksepakatan antara penulis diputuskan melalui forum diskusi. Data yang telah tersaring disajikan dalam tabel alur sesuai dengan item PRISMA (prefered items of systematic review and metaanalysis)(Liberati et al., 2009).Penilaian kualitas studi menggunakan NEWCASTLE - OTTAWA QUALITY ASSESSMENT SCALE COHORT STUDIES.Artikel yang tidak masuk dalam kriteria kualitatif, turut dibahas dan dijadikan sumber kepustakaan.

\section{Hasil}

\section{HASIL DAN PEMBAHASAN}

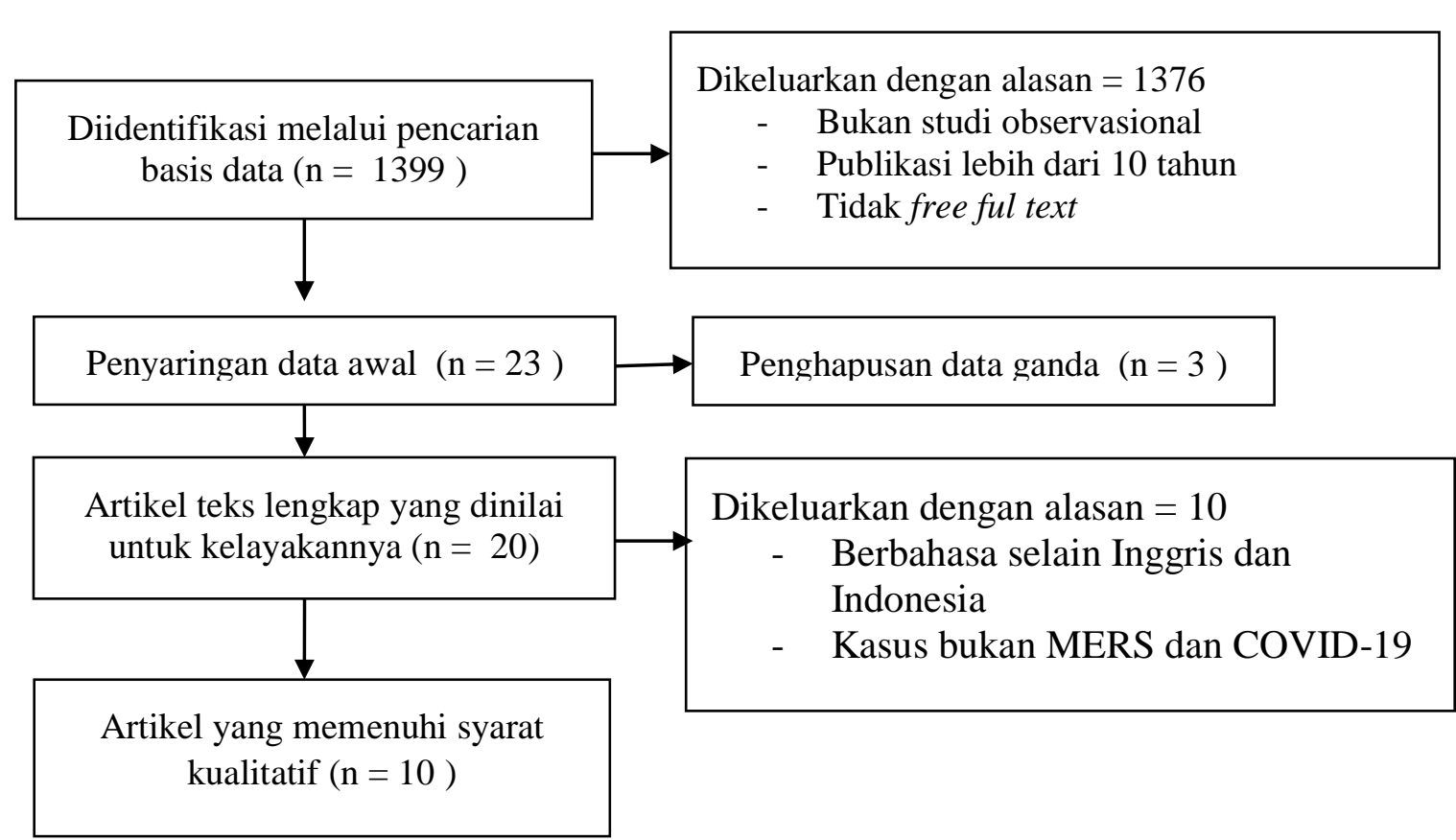

Gambar 1. Alur diagram PRISMA untuk seleksi artikel dalam tinjauan sistematis 
Tabel 1. Ringkasan Hasil Studi

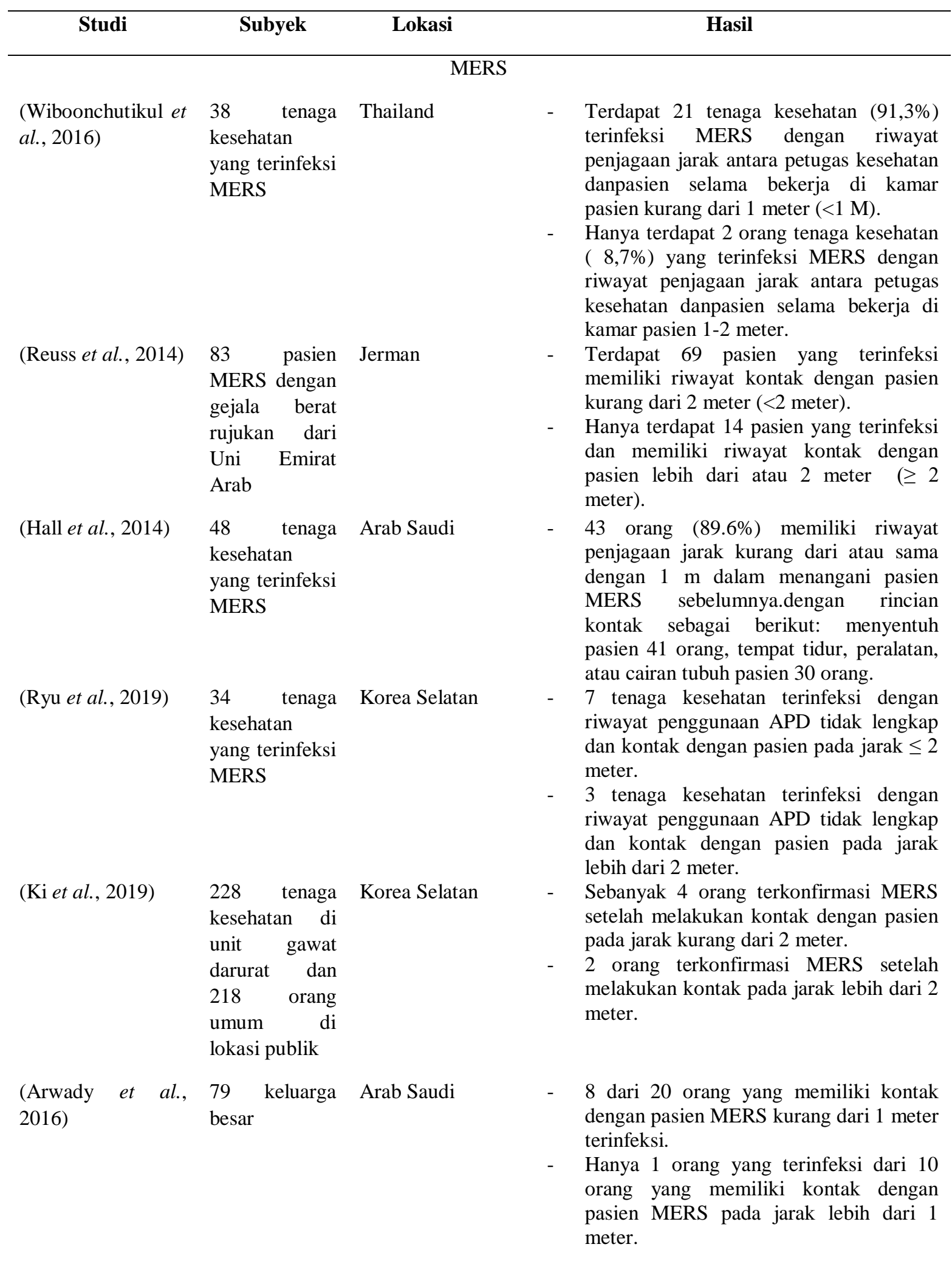




\section{SARS-CoV2 / COVID-19}

$\begin{array}{ll}\text { (Bai et al., 2020) } & 118 \text { tenaga } \\ \text { kesehatan di } \\ \text { Wuhan Cina }\end{array}$

(Burke et al., 2020) 78 orang yang memiliki kontak dengan 9 pasien COVID-19

(Heinzerling et al., 2020)
Amerika (USA) dengan pemantauan di fasilitas kesehatan dan ruang publik

- Tidak ada kasus infeksi pada 76 tenaga kesehatan yang menjaga jarak aman dengan pasien dan tidak melakukan kontak langsung.

- 12 dari 42 tenaga kesehatan yang memiliki riwayat kontak dengan pasien COVID-19 ikut tertular.

1. Lokasi pemantauan di fasilitas kesehatan

- $\quad 21$ orang yang memiliki kontak langsung dengan pasien 14 diantaranya harus melakukan pemeriksaan lanjutan karena dicurigai tertular dan 2 orang harus menjalani 2 kali tes.

- 7 orang yang memiliki kontak pada jarak $<6$ kaki (< 2 meter). 6 diantaranya harus melakukan pemeriksaan lanjutan karena dicurigai tertular dan 1 orang harus menjalani 2 kali tes.

- $\quad 11$ orang yang memiliki kontak langsung saat pasien batuk pada jarak $<6$ kaki $(<2$ meter). 10 diantaranya harus melakukan pemeriksaan lanjutan karena dicurigai tertular dan 1 orang harus menjalani 2 kali tes.

- 24 orang berada dalam 1 kendaraan dengan jarak duduk kurang dari 6 kaki ( 2 meter). 16 diantaranya harus menjalani tes lanjutan karena dicurigai tertular.

2. Lokasi Pemantauan di fasilitas publik

- 26 orang yang memiliki kontak langsung dengan pasien 22 diantaranya harus melakukan pemeriksaan lanjutan karena dicurigai tertular dan 4 orang harus menjalani 2 kali tes.

- 4 orang yang memiliki kontak pada jarak $<6$ kaki $(<2$ meter) dan semuanya harus melakukan pemeriksaan lanjutan karena dicurigai tertular.

- $\quad 20$ orang yang memiliki kontak langsung saat pasien batuk pada jarak $<6$ kaki $(<2$ meter). 18 diantaranya harus melakukan pemeriksaan lanjutan karena dicurigai tertular.

- 32 orang berada dalam 1 kendaraan dengan jarak duduk kurang dari 6 kaki ( 2 meter). 24 diantaranya harus menjalani tes lanjutan karena dicurigai tertular.

43 tenaga California , - - Tidak terdapat kasus penularan pada kesehatan di Amerika tenaga kesehatan yang menjaga jarak rumah sakit Serikat Solano County aman dengan pasien lebih jauh dari 1 meter dan kurang dari sama dengan 8 meter.

- Terdapat 3 tenaga kesehatan yang tertular 


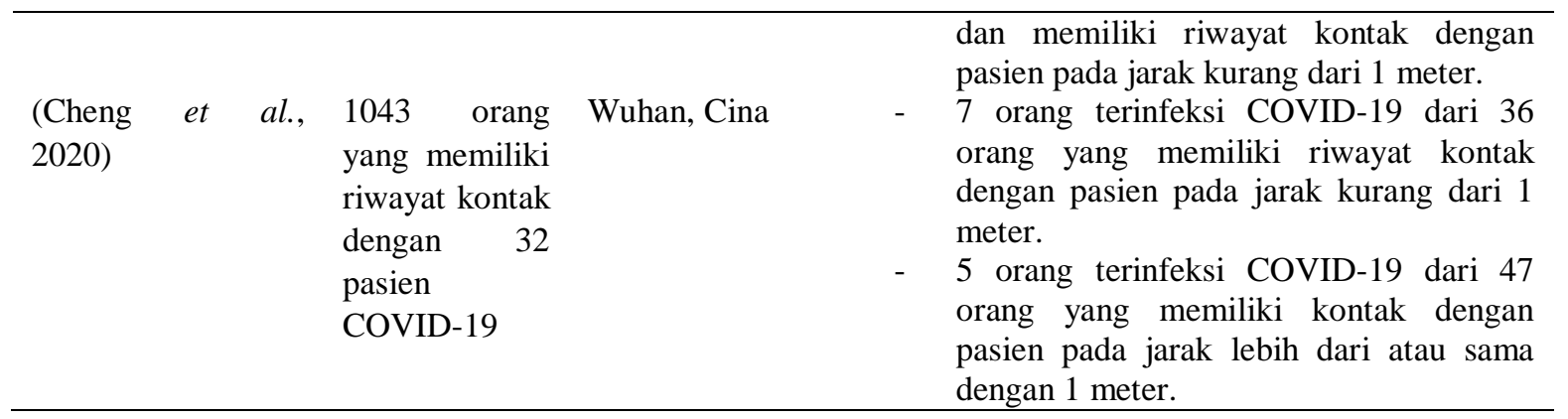

Tabel 2. Efektivitas Physical Distancing

\begin{tabular}{|c|c|c|c|}
\hline Studi & Kasus & $\begin{array}{l}\text { Unadjusted RR } \\
\quad(95 \% \mathrm{CI})\end{array}$ & RR gabungan (adjusted risk ratio) \\
\hline (Ki et al., 2019) & Middle & $0.72(0.14-3.70)$ & $0.23(95 \% \mathrm{CI}=0.04-1.20)$ \\
\hline $\begin{array}{l}\text { (Arwady et al., } \\
\text { 2016) } \\
\text { (Van Kerkhove et } \\
\text { al., 2019) }\end{array}$ & $\begin{array}{l}\text { Respiratory } \\
\text { Syndrome } \\
\text { (MERS) }\end{array}$ & $0.25(0.04-1.73)$ & $\begin{array}{l}4 \text { studi tidk dapat dihitung(Hall et al., 2014; } \\
\text { Reuss et al., 2014; Wiboonchutikul et al., } \\
\text { 2016; Ryu et al., 2019) }\end{array}$ \\
\hline (Bai et al., 2020) & \multirow{3}{*}{$\begin{array}{l}\text { Coronavirus } \\
\text { Disease } 2019 \\
\text { (COVID-19) }\end{array}$} & $0.02(0.001-0.37)$ & $0.20(95 \% \mathrm{CI}=0.10-0.41)$ \\
\hline (Burke et al., 2020) & & $0.04(0.003-0.68)$ & 2 studi tidak dapat dihitung(Liu and Zhang, \\
\hline $\begin{array}{l}\text { (Heinzerling et al., } \\
\text { 2020) }\end{array}$ & & $0.97(0.06-16.14)$ & \\
\hline (Cheng et al., 2020) & & $0.55(0.19-1.58)$ & \\
\hline
\end{tabular}

Sumber :(Dereket al, 2020)

\section{Pembahasan}

Berdasarkan hasil tinjauan sistematis, telah diketahui bahwa dalam menekan laju penularan virus COVID-19, kita mengacu pada pengalaman penanganan virus MERS dan SARS-CoV yang pertama. Penelitian telah menunjukan adanya hasil positif dalam penerapan physical distancing dengan penurunan infeksi.

Keseluruhan studi melaporkan bahwa angka infeksi cenderung lebih sedikit bahkan berkurang setengah bila setiap orang menjaga jarak dan kontak fisik dengan pasien terkonfirmasi MERS atau COVID-19, meski demikian jarak yang ditetapkan antar studi berbeda-beda.

Sebuah studi yang dilakukan oleh (Chu et al., 2020) terhadap 172 penelitiantentang COVID-19,SARS, dan MERS memberikan bukti untuk jarak kontak fisik yang baik adalah minimal 1 meter yang dikaitkan dengan penurunan infeksi danjarak 2 meter untuk penurunan kemungkinan infeksi yang lebih besar. 


\section{Konsep physical distancing (menjagajarak ) dalam upaya menangani pandemi}

Menjaga jarak baik fisik maupun interaksi sosial sebenarnya adalah upaya untuk melemahkan kurvapandemi,mencegah penularan infeksi yang tidak terkendali, memperlambat penyebaran, dan mengurangi beban rumah sakit. Konsep ini telah dipelajari selama satu abad lalu, ketika pasukan AS kembali dari Perang Dunia I dengan membawa virus flu Spanyol. Pandemi flu Spanyol telah membunuh sekitar 50 juta orang secara global (Fitzgerald, Nunn and Isaacs, 2020).

Pelajaran berharga terjadi ketika pemerintah Philadelphia (Amerika Serikat) tetap mengadakanLiberty Loan Parade pada 28 September 1918.Kerumunan masa menyaksikan pasukan, pengintai, dan marching band berparade di jalanan Philadelphia. Tiga hari kemudian, 31 rumah sakit di Philadelphia penuh dan dalam seminggu pawai 2.600 orang meninggal, sebaliknya kesehatan komisaris St Louis, Dr Max Starkloff, melarang pertemuan publik, menerbitkan editorial memberitahu orang-orang untuk menghindari keramaian, menutup bioskop dan ruang biliar, langkah ini ternyata dapat efektif menyelamatkan nyawa penduduk, sejarah mencatat kematian di Philadelphia adalah delapan kali lebih tinggi daripada di St Louis (Mukherjee, 2020).

Mempelajari fenomena tersebut, para ahli kesehatan dunia sepakat untuk melakukan penjagaan jarak baik fisik maupun interaksi sosial selama terjadinya penyebaran dan penularan penyakit. Konsep ini lalu terus digunakan dan diterapkan dalam beberapa kasus pandemi, kasus influenza yang telah terjadi seblum COVID-19 diantaranya SARS-CoV dan middle east respiratory syndrome (MERS).

\section{Efektivitas physical distancing secara statistik}

Berdasarkan hasil meta analisis yang dilakukan oleh (Derek K et al, 2020) beberapa studi yang menyajikan data terkait jumlah pasien-pasien yang memiliki riwayat kontak dan terinfeksi virus MERS dan COVID-19 dianalisis secara statistik. Hasil menunjukan bahwa penerapan physical distancing dapat mengurangi risiko kejadian MERS sebanyak 0.23 kali atau 23\% meskipun hasil ini tidak signifikan. Sebaliknya untuk kasus SARS-CoV2 atau COVID-19 penerapan pembatasan fisik ini dapat menurunkan risiko kejadian terinfeksi sebesar 0.20 kali atau $20 \%$ dan hasil yang didapatkan dari kumulatif perhitungan signifikan.

Perbedaan hasil antara 2 kasus ini banyak dipengaruhi oleh ketersediaan studi primer dan kurangnya jumlah sampel, namun dalam kasus penyakit infeksi yang mengancam nyawa segala upaya yang terbukti dapat menurunkan risiko keterpaparan patut dicoba, penulis beranggapan itulah dasar diterapkannya physical distancing pada kasus COVID-19 yang mengacu pada hasil penerapan langkah serupa saat infeksi MERS.

\section{Potensi risiko penerapan physical distancing}

Studi sebelumnya telah melaporkan potensi merugikan dan efek psikososial yang negatifdari physical distancing.Kemampuan melakukan penjarakan fisik dansosial telah menjadi perhatian, banyak masyarakat yang tidak mampu melakukan ini dan rusaknya tatanan sosial dalam kehidupan 
bermasyarakat,kaum muda dan orang tua paling menderita dalam setiap robekan atau perubahan dalam tatanan sosial (Brooks et al., 2020; Fitzgerald, Nunn and Isaacs, 2020; Pfefferbaum and North, 2020).

Efek psikologis cenderung beragam, mungkinmenjadi jangka pendek atau panjang, atau akut pada kerugian yang sebelumnya, ada dua masalah jangka panjang, efek jangka panjang yang berkaitan dengan masalah fisik dan psikologis adalahkemungkinan tromboemboli,sifat Covid-19 yang mengarah pada perkembangan radang pembuluh darah kecil di otak - endotelitis - yang mungkin meningkatkan kemungkinan kecemasan, depresi, psikosis dan gangguan neuropsikiatri yang sama seperti pandemi flu pada awal abad ke-20 (Hacohen et al., 2020; Helms et al., 2020).

Efek psikososial jangka panjang lainnya adalah hilangnya kepercayaan orang muda pada kompetensi orang tua, korupsi skala luas, dan ketidakpedulian masyarakat terhadap perbaikan ekonomi(Frasquilho et al., 2016; Durrheim, Gostin and Moodley, 2020).Kaum muda telah diminta untuk bersikap dan berkebiasaan sehat dengan menerapkan protokol kesehatan demi melindungiorang yang lebih tua. Implikasinya orang tua harus bersikaptanggung jawab untuk melindungi kaum muda di masa depan.

\section{Resiko bias dan kekurangan penelitian}

Systematic review atau tinjauan sistematis ini, masih terdapat risiko bias yang disebabkan oleh berbagai hal diantaranya: bias publikasi, biar seleksi dimana sampel yang dipilih lebih banyak merupakan tenaga kesehatan atau orang-orang yang bekerja di bidang kesehatan dibandingkan masyarakat umum, hal ini dipahami karena upaya pelacakan yang akan lebih sulit.

Hasil review dari artikel primer juga menunjukan beberapa kekurangan dan bias tentang pengukuran dari penjarakan fisik yang diterapkan. Penjarakan berkisar antara kurang dari 1 meter hingga lebih dari 2 meter. Penilaian studi juga berpotensi menimbulkan bias karena studi observasional yang menganalisis tentang topik ini tidak banyak dan tidak dalam satu desain yang sama.

\section{SIMPULAN DAN SARAN}

\section{Simpulan}

Menjaga jarak fisik dan interaksi sosial merupakan salah satu upaya pengendalian infeksi dengan tujuan melemahkan dan melandaikan kurva pandemi, secara statistik upaya ini memberikan hasil penurunan risiko penularan pada kasus MERS dan COVID-19, namun beberapa hasil yang dilaporkan tidak signifikan sehingga masih dibutuhkan upaya lain untuk mengontrol penyebaran dan infeksi. Upaya lain yang harus dilakukan bersamaan dengan physical distancing antara lain: memakai masker, sering mencuci tangan dengan air bersih yang mengalir dan menggunakan sabun, menjauhi kerumunan, dan selalu menerapkan kebersihan diri.

\section{Saran}

Penerapan praktik 3T (tracing, testing, treatment)sama pentingnya dengan penerapan perilaku 3M (menggunakan masker, mencuci tangan, menjaga jarak). 
Kedua hal tersebut adalah upaya untuk memutus mata rantai penularan COVID19.Penerapan praktik $3 \mathrm{~T}$ masih perlu ditingkatkan pemahamannya di masyarakat, mengingat masyarakat lebih mengenal 3M yang kampanyenya dilakukan terlebih dahulu dan gencar.

\section{DAFTAR PUSTAKA}

Andersen, K. G. et al. (2020) 'Epidemiological and clinical characteristics of 99 cases of 2019 novel coronavirus pneumonia in Wuhan, China: a descriptive study', The Lancet. doi: 10.1056/NEJMc1915189.

Arwady, M. A. et al. (2016) 'Middle east respiratory syndrome coronavirus transmission in extended family, Saudi Arabia, 2014', Emerging Infectious Diseases, 22(8), pp. 1395-1402. doi: 10.3201/eid2208.152015.

Atmojo, J. T., Iswahyuni, S., Rejo, R., Setyorini, C., Puspitasary, K., Ernawati, H.et al. (2020). PENGGUNAAN MASKER DALAM PENCEGAHAN DAN PENANGANAN COVID-19: RASIONALITAS, EFEKTIVITAS, DAN ISU TERKINI. Avicenna: Journal of Health Research, 3(2).doi: 10.36419/avicenna.v3i2.420.

Bai, Y. et al. (2020) 'SARS-CoV-2 infection in health care workers: a retrospective'.

Brooks, S. K. et al. (2020) 'The psychological impact of quarantine and how to reduce it: rapid review of the evidence', The Lancet. doi: 10.1016/S01406736(20)30460-8.

Burke, R. M. et al. (2020) 'Enhanced contact investigations for nine early travelrelated cases of SARS-CoV-2 in the United States', medRxiv. doi: 10.1101/2020.04.27.20081901.

Cheng, H. Y. et al. (2020) 'High transmissibility of COVID-19 near symptom onset', medRxiv. doi: 10.1101/2020.03.18.20034561.

Chu, D. K. et al. (2020) 'Physical distancing, face masks, and eye protection to prevent person-to-person transmission of SARS-CoV-2 and COVID-19: a systematic review and meta-analysis', The Lancet, 395(10242), pp. 1973-1987. doi: 10.1016/S0140-6736(20)31142-9.

Derek K Chu, Elie A Akl, Stephanie Duda, Karla Solo, Sally Yaacoub, H. J. S. (2020) 'Physical distancing, face masks, and eye protection to prevent person-to-person transmission of SARS-CoV-2 and COVID-19: a systematic review and meta-analysis Derek K Chu, Elie A Akl, Stephanie Duda, Karla Solo, Sally Yaacoub, Holger J Schünemann, on beha', Lancet, 395(June), pp. 1973-1987. doi: 10.1016/S0140-6736(20)311429.

Durrheim, D. N., Gostin, L. O. and Moodley, K. (2020) 'When does a major outbreak become a Public Health Emergency of International Concern?', The Lancet Infectious Diseases. doi: 10.1016/S1473-3099(20)30401-1.

Fitzgerald, D. A., Nunn, K. and Isaacs, D. (2020) 'Since January 2020 Elsevier has created a COVID-19 resource centre with free information in English and Mandarin on the novel coronavirus COVID- 19. The COVID-19 resource centre is hosted on Elsevier Connect, the company' s public 
news and information ', (January).

Frasquilho, D. et al. (2016) 'Unemployment, Parental Distress and Youth Emotional Well-Being: The Moderation Roles of Parent-Youth Relationship and Financial Deprivation', Child Psychiatry and Human Development. doi: 10.1007/s10578-015-0610-7.

Hacohen, Y. et al. (2020) 'Neurologic and Radiographic Findings Associated with COVID-19 Infection in Children', JAMA Neurology. doi: 10.1001/jamaneurol.2020.2687.

Hall, A. J. et al. (2014) 'Health care worker contact with MERS patient, Saudi Arabia', Emerging Infectious Diseases. doi: 10.3201/eid2012.141211.

Handayani, R. T., Suminanto, S., Darmayanti, A. T., Widiyanto, A., \& Atmojo, J. T. (2020). Conditions and Strategy for Anxiety in Health Workers at Pandemic Covid-19. Jurnal Ilmu Keperawatan Jiwa, 3(3), 365-374. doi: $10.32584 /$ jikj.v3i3.643.

Heinzerling, A. et al. (2020) 'Transmission of COVID-19 to Health Care Personnel During Exposures to a Hospitalized Patient - Solano County, California, February 2020', MMWR. Morbidity and Mortality Weekly Report. doi: 10.15585/mmwr.mm6915e5.

Helms, J. et al. (2020) 'Neurologic Features in Severe SARS-CoV-2 Infection', New England Journal of Medicine. doi: 10.1056/nejmc2008597.

Jefferson, T. et al. (2020) 'Physical interventions to interrupt or reduce the spread of respiratory viruses', The Cochrane database of systematic reviews, 11, p. CD006207. doi: 10.1002/14651858.CD006207.pub5.

Van Kerkhove, M. D. et al. (2019) 'Transmissibility of MERS-CoV infection in closed setting, Riyadh, Saudi Arabia, 2015', Emerging Infectious Diseases. doi: 10.3201/eid2510.190130.

Ki, H. K. et al. (2019) 'Risk of transmission via medical employees and importance of routine infection- prevention policy in a nosocomial outbreak of Middle East respiratory syndrome ( MERS ): a descriptive analysis from a tertiary care hospital in South Korea', pp. 1-12.

Liberati, A. et al. (2009) 'The PRISMA statement for reporting systematic reviews and meta-analyses of studies that evaluate healthcare interventions: explanation and elaboration', Bmj, 339(jul21 1), pp. b2700-b2700. doi: 10.1136/bmj.b2700.

Liu, X. and Zhang, S. (2020) 'COVID-19: Face masks and human-to-human transmission', Influenza and other Respiratory Viruses, 14(4), pp. 472473. doi: 10.1111/irv.12740.

Mukherjee, N. (2020) 'A Case Study on the Spanish Flu 1918 - How it burrowed Into the City of New Orleans', International Journal of Science and Research (IJSR). doi: 10.21275/sr20811114948.

Park, S., Kim, B. and Lee, J. (2020) 'Social Distancing and Outdoor Physical Activity During the COVID-19 Outbreak in South Korea: Implications for Physical Distancing Strategies', Asia-Pacific Journal of Public Health, 32(6-7), pp. 360-362. doi: 10.1177/1010539520940929. 
Pfefferbaum, B. and North, C. S. (2020) 'Mental Health and the Covid-19 Pandemic', New England Journal of Medicine. doi: 10.1056/nejmp2008017.

Rejo, R., Arradini, D., Darmayanti, A. T., Widiyanto, A., \& Atmojo, J. T. (2020). Factors Related to the Depression of Health Workers During the Covid19 Pandemic. Jurnal Ilmu Keperawatan Jiwa, 3(4), 495-502. doi: 10.32584/jikj.v3i4.682.

Reuss, A. et al. (2014) 'Contact investigation for imported case of middle east respiratory syndrome, Germany', Emerging Infectious Diseases. doi: 10.3201/eid2004.131375.

Ryu, B. et al. (2019) 'Seroprevalence of Middle East respiratory syndrome coronavirus (MERS-CoV) in public health workers responding to a MERS outbreak in Seoul, Republic of Korea, in 2015', Western Pacific surveillance and response journal: WPSAR. doi: 10.5365/wpsar.2018.9.3.002.

Wang, D. et al. (2020) 'Clinical Characteristics of 138 Hospitalized Patients with 2019 Novel Coronavirus-Infected Pneumonia in Wuhan, China', JAMA Journal of the American Medical Association, 323(11), pp. 1061-1069. doi: 10.1001/jama.2020.1585.

Wiboonchutikul, S. et al. (2016) 'Lack of transmission among healthcare workers in contact with a case of Middle East respiratory syndrome coronavirus infection in Thailand', Antimicrobial Resistance and Infection Control. doi: 10.1186/s13756-016-0120-9.

World Health Organization (2020) 'WHO | What is a pandemic?', World Health Organization. 